ASIAN RIVALRIES 



\title{
ASIAN RIVALRIES
}

Conflict, Escalation, and Limitations on Two-level Games

\author{
Edited by Sumit Ganguly \\ and William R. Thompson
}

Stanford Security Series, An Imprint of Stanford University Press Stanford, California 
Stanford University Press

Stanford, California

(C) 2011 by the Board of Trustees of the Leland Stanford Junior University.

All rights reserved.

No part of this book may be reproduced or transmitted in any form or by any means, electronic or mechanical, including photocopying and recording, or in any information-storage or -retrieval system without the prior written permission of Stanford University Press.

Indiana University gratefully acknowledges the invaluable contributions of our partner, the Strategic Studies Institute of the U.S. Army War College. In 2009, the Strategic Studies Institute and Indiana University joined to collaborate on the publication of a scholarly work examining contemporary and historic Asian conflicts while employing rivalry theory as a framework for comparative analysis. The goal of our conference was to focus on an area that is ripe with political relevance, write chapters rich in narrative detail, and produce a final product that provides insight into the common themes associated with the origins and resolutions of rivalries in Asia and other regions. We believe this book achieves those goals, and Indiana University readily recognizes that we could not have accomplished our objectives without the intellectual, personnel, and financial support of the Strategic Studies Institute.

We would like to acknowledge the substantial assistance of Vera Heuer, a doctoral student in the Department of Political Science at Indiana University, Bloomington, for her help in organizing the conference that culminated in this volume.

Special discounts for bulk quantities of Stanford Security Studies are available to corporations, professional associations, and other organizations. For details and discount information, contact the special sales department of Stanford University Press. Tel: (650) $736-1782$, Fax: (650) 736-1784

Printed in the United States of America on acid-free, archival-quality paper.

Library of Congress Cataloging-in-Publication Data

Asian rivalries : conflict, escalation, and limitations on two-level games / edited by Sumit Ganguly and William R. Thompson.

pages $\mathrm{cm}$

Includes bibliographical references and index.

ISBN 978-0-8047-7595-3 (cloth : alk. paper)

ISBN 978-0-8047-7596-o (pbk : alk. paper)

1. Asia-Foreign relations-1945- 2. Asia-Politics and government-1945-

I. Ganguly, Sumit, editor of compilation. II. Thompson, William R., editor of compilation.

DS35.2.A8365 2011

327.5 - dc22 